\section{Ethical Lingua}

Journal of Language Teaching and Literature

ISSN 2355-3448 (Print)

ISSN 2540-9190 (Online)

Volume 4, Number 2, August 2017

pp. $139-150$.

\title{
Think Talk Write Strategy toward Students' Writing Ability
}

\author{
Rizka Indahyanti \\ rizkaindahyanti@uim-makassar.ac.id \\ Universitas Islam Makassar, Indonesia
}

Accepted : 17 July 2017

URL : : http://journal.uncp.ac.id/index.php/ethicallingua/article/view/627

\begin{abstract}
The objective of this research was to find out whether or not the implementation of Think Talk Write (TTW) strategy improves students' writing ability. The researcher applied quasi-experimental method. The population of this research is the second semester students of English Language Education. There were two classes and it consists of 60 students. The researcher used cluster random sampling technique and divided the class into two groups, one group as experimental group and another as control group. Therefore, each group consisted of 30 students. Based on the students' result obtained and stated in findings, the researcher used t-test in inferential statistic through SPSS to test the hypothesis. It showed that the probability value is lower than alpha $(\alpha)(0.000<0.05)$. It means that $H_{1}$ was accepted and $\mathrm{H}_{0}$ was rejected. Therefore, it can be concluded that the implementation of Think Talk Write (TTW) strategy improves students' writing achievement.
\end{abstract}

Keywords: think talk write strategy, writing ability

\section{Introduction}

Learning language acquires the ability to compose correct sentences. It implies that writing plays a very important role in learning language. Most people tend to have the same opinion that writing is the most difficult skill among the other skills. They consider that an ability in writing is a talent that one either has or does not have. This is not necessarily true. One can write effectively by having good knowledge of grammar and organization. However, writing is not an easy work. Writing is learned behavior that takes a long time to master. Writing ability takes study and practice to develop this skill. It needs the study of linguistics and non-linguistics factors. The linguistics factors are vocabulary, grammar, structure, orthography, and so on. Non-linguistics factors are reading habit, motivation, knowledge of the world, and learning strategies. It also requires practice as well. One must note that writing is a process in which practice must be exercised continuously. 
Related to the statement above and what the researcher observed in the field, she found that most of the students' writing scores in English Language Education were still under the minimum passing criteria and were still unsatisfactory. Generally, the students got difficult in generating ideas and organized them into a good paragraph. They made a number of mistakes in their writing in terms of content, organization, vocabulary, grammar, and mechanic. Those problems arose because the lecturer seems not to use an appropriate strategy in teaching writing.

On this unsatisfactory condition, the researcher wants to find a solution to overcome the problems about writing. Think Talk Write is a good strategy to be implemented because it consists of the Think step (the comprehension process through reading materials, making notes, and the responds towards the reading materials), Talk (the process of delivering the ideas of their comprehension through the interaction either with their friends, their lecturer, or the formal group discussion), and Write (the process of delivering the ideas of their comprehension through writing built individually by the students). This strategy referenced is expected to improve the students' achievement in writing.

\section{Concept of Writing}

Many linguists have given some definitions about writing. According to Eanes (1997), writing is a valuable tool for learning in a number of ways. Writing helps students reflect on how much they already know about a topic. It encourages students to assess how well they understand new information at depeer levels, the students should be provided with the frequent opportunities to write for a variety purposes. Furthermore, Oshima \& Hougue (1997: 2) describes that writing is a progressive activity. This means that when you first write something down, you have already been thinking about what you are going to say and how you are going to say it. Then after you have finished writing, you read over what you have written and make changes and correction. Therefore, writing is never a one-step action. It is a process that has several steps.

Jacobs et al. (1981) point out five components of writing. They are content, organization, vocabulary, language use and mechanics. Content means the component of writing should be clear to the readers. So that readers can understand the message conveyed and gains the information from it. In order to have a good content of writing, its contents should be well unified and complete. Then, the term usually known as unity and complements which become characteristics of the good writing. Besides writing has completeness, the main idea has to be explained and develop fully. Completeness is the controlling ideas which developed thoroughly by the use of particular information. Unity means that every part of sentence contributes to one principle, unifying thought. Furthermore, unity is the first quality of effective sentence. When we say that a sentence has unity, we mean that everything in it, has a logical relation to the purpose of the sentences as a whole and nothing is omitted which is necessary to that purpose.

Organization means the process of organization materials in writing involves coherence, order of importance, general to specific, specific to general, chronological order, and spatial pattern. Another component is vocabulary. One of the requirements of a good writing always depends on the effective use of 
words. In personal description, word plays a dual role: to communicate and to evoke to the readers to perceive and feel. The last component is mechanics. The use of mechanics is due to capitalization, punctuation, and spelling appropriately. This aspect is very important since it leads readers to understand or recognize immediately what the writer means to express definitely. The use of favorable mechanics in writing will make readers easy to understand the conveying ideas or the messages stated in the writing.

\section{Narrative Writing}

Meyers (2005: 52) states that narrative is one of the most powerful ways of communicating with others. A good written story lets your reader response to some event in your life as if it were own. They not only understand the event, but they can almost feel it. The action, details, and dialogue put the readers in these seem and make it happen for them. Narrative text is also known as a creative writing. A narrative writer writes to amuse or entertain the readers with actual or imaginary experience in different ways. Narrative always deals with some problems which lead to the climax and then turn into a solution to the problem. Therefore a fully developed narrative fiction or nonfiction should have a central theme that has to be introduced in the beginning, followed by the development of the theme and an eventual middle and memorable end. According to Parker (1983), a narrative can be based on an actual experience, or it can be a totally imaginary, or it can be a mixture of both reality and imagination. In any case, a narrative is an account of events told in such a way that the readers share the writer's experience. A narrative paragraph begins with a general statement - like topic sentence - that tells the reader what the story will be about.

Narrative text maybe either fiction or non-fiction. Examples of fiction include realistic fiction, science fiction, mysteries, folk tales, fairy tales, and myths. Nonfiction is fact-based text such as report, fact-based students' experience or factual stories, and biographies. Narrative text has five common components, namely:
1. Setting
Where or when the story takes place
2. Characters
3. Plot
People or animals in the story
4. Theme
Sequence of events
Central idea of the story
5. Vocabulary
Words used to enrich understanding of the story.

The purpose of narrative is to entertain, or amuse the readers and the basic purpose of narrative is to entertain, to gain, and to hold a reader's interest. However narrative can also be written to teach or to inform, to changes attitudes/social opinions e.g. soap operas and television dramas that are used to raise topical issues. Narrative sequence people/characters in time and place but differ from recounts in that through the sequencing. The stories set up one or more problems, which must eventually find a way to be resolved.

\section{Definition of Think Talk Write (TTW) Strategy}

Think Talk Write (TTW) strategy was introduced by Huinker \& Laughlin (1996: 82 ) on the grounds that Think Talk Write strategy is to build precisely to think and reflect and to organize ideas and to test the idea before students at the asked to write. It is a strategy that facilitates language exercises orally and write the language fluently. 
This strategy is based on the understanding that learning is a social behavior. It's encourages students to think, speak, and then write with regard to a topic. Think Talk Write is used to develop writing and practicing the language fluently before writing. It's allows students to influence and manipulate ideas before writing. The strategies also assist students in gathering and developing ideas through structured conversations.

In learning activities that are often encountered when students are given written assignments, students are always trying to directly start writing answers. Although it is not something wrong, but would be more meaningful if he first did the thinking, reflect on and develop ideas, and test ideas before starting to write. Think Talk Write (TTW) Strategies is built by providing time for students to perform these activities (to think, reflect and to formulate ideas, and test ideas before writing it).

The Stages of Think Talk Write (TTW) Strategy are as follows:

1. The first phase of student learning activity is to think, namely the stage of thinking in which students read the text in the form of questions (if let's start with the question of dealing with everyday problems of students or contextual). In this stage individual students to think of possible answers (solving strategies), making little notes about the ideas contained in the readings, and things that are not understood in accordance with its own language.

2. The second stage is to talk (talk or discussion) to give students the chance to talk about the investigation at first stage. At this stage the students reflect, arrange, as well as test (negotiation, sharing) ideas in group discussions. Progress communication students will look at the dialogue in discussions both in exchanging ideas with others or their own reflection it reveals to others.

3. The third stage is to write, students write down ideas that are acquired and the first and second phase activities. This paper consists of grounding the concepts used, the linkage with the previous material, solving strategies, and solutions are obtained.

According to Silver and Smith (1996: 21), the role and duties of teachers in an effort to make effective use of Think Talk Write (TTW) Strategies is to ask and provides tasks that allow students to engage actively thinking, encourage and listen carefully to the ideas put forward students orally and in writing, to consider and provide information about what students explored in the discussion, and to monitor, assess, and encourage students to participate actively. Prepared task is expected to trigger students to work actively the questions which have answers to divergent or open-ended task.

To realize the hope of learning in accordance with the above, designed learning to follow the following steps:

1. Students read the text and make notes of the individual readings (think), to be brought into the discussion forum.

2. Students interact and collaborate with friends with a group to discuss the contents of the note (talk). In this activity, they use language and words 
themselves to convey mathematical ideas in the discussion. Understanding is built through interaction in the discussion. Discussions are expected to produce a solution to the given problem.

3. Students construct their own knowledge and communication mathematics in writing (write).

4. Activities end of the lesson is to make reflections and conclusions on the material being studied. Prior to that selected one or several of his students as a group representative to present the answer, while another group was asked to respond.

\section{Methodology}

The method used in this research is quasi-experimental method in which two groups are involved. They are experimental group and control group. Pre-test is administered before treatment while post-test is administered after treatment to measure its effect. The design of this research is described as follows:

$$
\begin{array}{llll}
\text { E: } & \mathrm{O}_{1} & \mathrm{X}_{1} & \mathrm{O}_{2} \\
\mathrm{C}: & \mathrm{O}_{1} & \mathrm{X}_{2} & \mathrm{O}_{2}
\end{array}
$$

(Gay, 2006: 255)

Note:

E : Experimental Group

C : Control Group

$\mathrm{O}_{1} \quad$ : Pre-test

$\mathrm{O}_{2} \quad$ : Post-test

$\mathrm{X}_{1} \quad$ : Treatment by using Think Talk Write Strategy

$\mathrm{X}_{2} \quad$ : Treatment without Think Talk Write Strategy

The hypothesis of this experiment is formulated as follows:

H1: $\quad$ Think Talk Write (TTW) strategy improves students' writing achievement

H0: $\quad$ Think Talk Write (TTW) strategy does not improve students' writing achievement

\section{Population and Sample}

The population of this research is the second semester students of English Language Education of Universitas Islam Makassar. There were two classes and it consists of 60 students. The researcher used cluster random sampling technique and divided the class into two groups, one group as experimental group and another as control group. Therefore, each group consisted of 30 students.

\section{Research Instrument}

The instrument used in this research was writing test, as the main data, is used in pretest and posttest. The pretest is intended to investigate the students' prior knowledge on English writing before giving treatment while the posttest is given to measure the students' achievement on English writing after the treatment has been given.

\section{Procedure of Collecting Data}

The procedure of collecting data is chronologically performed as follows: 


\section{Pre-test}

The pre-test is administered to the students to find their achievement before giving treatment. The procedures are as follows:

a. The researcher distributes the test to the students.

b. The researcher gives test direction to the students.

c. The researcher controls the students when they do the test.

d. The researcher collects the students' worksheet after the test.

\section{Treatment}

\section{Experimental group}

The procedures of teaching and learning process (treatment) are presented as follows:

1. The researcher greets the students

2. The researcher asks the students about their feeling

3. The researcher introduces Think Talk Write strategy to the students.

4. The researcher gives the chance for students to ask unclear information

5. Students read the text and make notes of the individual readings (think), to be brought into the discussion forum.

6. Students interact and collaborate with friends with a group to discuss the contents of the note (talk). In this activity, they use language and words themselves to convey the ideas in the discussion. Understanding is built through interaction in the discussion. Discussions are expected to produce a solution to the given problem.

7. Students construct their own knowledge and communication in writing (write).

8. Activities end of the lesson is to make reflections and conclusions on the material being studied. Prior to that selected one or several of his students as a group representative to present the answer, while another group was asked to respond.

9. The researcher asks the students to submit their narrative text

10. The researcher gives some tips to improve their writing

11. The researcher informs the students what they are going to do in the next meeting

\section{Control group}

1. The researcher greets the students

2. The researcher asks the students about their feeling

3. The researcher introduces narrative text to the students

4. The researcher asks the students to read some examples of narrative text from book.

5. The researcher explains the stages and components of writing

6. The researcher asks the students to write short narrative text individually

7. The researcher monitors the students' activities in the class.

8. The researcher gives the chance for students to ask unclear information

9. The researcher asks the students to submit their narrative text

10. The researcher gives some tips to improve their writing

11. The researcher informs the students what they are going to do in the next meeting 


\section{Post-test}

Posttest is administered to see the value of the treatment using Think Talk Write (TTW) strategy. The test given is the same as the test before.

\section{Technique of Data Analysis}

In this research, the data are analyzed through quantitative analysis. To get the score, the researcher uses scoring scale which includes the content, organization, vocabulary, language use and mechanics on the students' process of writing, the data are analyzed by employing the following procedures:

a. Scoring the result of the students' test

b. Classifying the score of the students

c. Calculating the mean score and deviation standard by using SPSS 17

To measure the quality of students' writing score on five components observed, the data are classified into five classification by referring to the classification of system score that used by Depdiknas.

Table 1. Students' score

\begin{tabular}{ccl}
\hline No. & Scores & Classification \\
\hline 1 & $86-100$ & Very good \\
2 & $71-85$ & Good \\
3 & $56-70$ & Average \\
4 & $41-55$ & Poor \\
5 & $0-40$ & Very poor \\
\hline
\end{tabular}

Classifying the score of the students, the researcher uses the scoring rubrics proposed by Jacobs et al. (1981: 91) and Trible in Naidu (2007) with revision as follows:

Table 2. Scoring Rubrics

\begin{tabular}{ccc}
\hline Area & Score & \multicolumn{1}{c}{ Descriptor } \\
\hline Content & $27-30$ & $\begin{array}{l}\text { Excellent to very good: Excellent to very } \\
\text { good treatment of the subject; considerable } \\
\text { variety of ideas, independents and thorough } \\
\text { interpretation; content relevant to the topic; } \\
\text { accurate detail } \\
\text { Good to average: Adequate treatment of } \\
\text { topic: some variety of ideas or argument; some } \\
\text { independence of interpretation of the topic; } \\
\text { most content relevant to the topic; reasonably } \\
\text { accurate detail } \\
\text { Fair to poor: Treatment of the topic is hardly } \\
\text { adequate; little variety of ideas; some } \\
\text { irrelevant content; lacking detail. } \\
\text { Very poor: Inadequate treatment of the topic; } \\
\text { no variety of ideas or argument; content } \\
\text { irrelevant; almost no useful detail. }\end{array}$ \\
\hline $17-21-26-16$ &
\end{tabular}

\begin{tabular}{ccl}
\hline Area & Score & \multicolumn{2}{c}{ Descriptor } \\
\hline Organization & $18-20$ & $\begin{array}{l}\text { Excellent to very good: Fluent expression, } \\
\text { ideas clearly stated and supported; } \\
\text { appropriately organized paragraphs or }\end{array}$
\end{tabular}




\begin{tabular}{cl}
\hline $14-17 \quad \begin{array}{l}\text { sections; logically sequenced; connectives } \\
\text { appropriately used. } \\
\text { Good to average: Uneven expression, but } \\
\text { main ideas stand out; paragraphing or section } \\
\text { organization evident; logically sequence; some } \\
\text { connectives used. }\end{array}$ \\
$\begin{array}{l}\text { Fair to poor: Very uneven expression, ideas } \\
\text { is difficult to follow; organization does not help } \\
\text { reader; logical sequence is difficult to follow; } \\
\text { connectives are largely absent. } \\
\text { Very poor: Lacks fluent expression; ideas is } \\
\text { very difficult to follow; little sense of } \\
\text { organization; no sense of logical sequence; } \\
\text { connectives are not used. }\end{array}$ \\
\hline
\end{tabular}

\begin{tabular}{ccc}
\hline Area & Score & \multicolumn{1}{c}{ Descriptor } \\
\hline Vocabulary & $18-20$ & $\begin{array}{l}\text { Excellent to very good: Wide range of } \\
\text { vocabulary; accurate word / idiom choice and } \\
\text { usage; appropriate selection to match register. } \\
\text { Good to average: Adequate range of } \\
\text { vocabulary; occasional mistakes in word / } \\
\text { idiom choice and usage; register is not always } \\
\text { appropriate. } \\
\text { Fair to poor: Limited range of vocabulary; a } \\
\text { noticeable number of mistakes in word / idiom } \\
\text { choice and usage; register is not always } \\
\text { appropriate. } \\
\text { Very poor: No range of vocabulary; } \\
\text { uncomfortably frequent word / idiom choice } \\
\text { and usage; no apparent sense of register. }\end{array}$ \\
\hline
\end{tabular}

\begin{tabular}{|c|c|c|}
\hline Area & Score & Descriptor \\
\hline \multirow[t]{4}{*}{ Language use } & $22-25$ & $\begin{array}{l}\text { Excellent to very good: Confident handling of } \\
\text { appropriate structures, hardly any errors on } \\
\text { agreement, tense, number, word order, articles, } \\
\text { pronouns, prepositions; meaning never obscured. }\end{array}$ \\
\hline & $18-21$ & $\begin{array}{l}\text { Good to average: Acceptable grammar - but } \\
\text { problems with more complex structure; mostly } \\
\text { appropriate structures, some errors on agreement, } \\
\text { tense, number, word order, articles, pronouns, } \\
\text { prepositions; meaning sometimes obscured. }\end{array}$ \\
\hline & $11-17$ & $\begin{array}{l}\text { Fair to poor: Insufficient range of structures with } \\
\text { control only shown in simple constructions; } \\
\text { frequent errors on agreement, tense, number, word } \\
\text { order, articles, pronouns, prepositions; meaning } \\
\text { sometimes obscured. }\end{array}$ \\
\hline & $5-10$ & $\begin{array}{l}\text { Very poor: Major problems with structures-even } \\
\text { simple ones; frequent errors of negotiation, } \\
\text { agreement, tense, number, word order/function, } \\
\text { articles, pronouns, prepositions; meaning often } \\
\text { obscured. }\end{array}$ \\
\hline
\end{tabular}




\begin{tabular}{ccl}
\hline Area & Score & \multicolumn{1}{c}{ Descriptor } \\
\hline Mechanics & 5 & $\begin{array}{l}\text { Excellent to very good: Demonstrate full } \\
\text { command of spelling, punctuation, } \\
\text { capitalization, and layout. } \\
\text { Good to average: Occasional errors in } \\
\text { spelling, punctuation, capitalization, and } \\
\text { layout. } \\
\text { Fair to poor: Frequent errors in spelling, } \\
\text { punctuation, capitalization, and layout. } \\
\text { Very poor: Fails to address this aspect of the } \\
\text { task with any effectiveness. }\end{array}$ \\
\hline
\end{tabular}

\section{Findings}

As the researcher explained in the previous chapter that to collect the data in this research, the researcher used pre-test and post-test in which these tests aimed at collecting data of the students' ability to write narrative of two groups, the experimental group and the control group.

\section{The students' Ability in Writing Narrative}

This section deals with the presentation of the result of the students' ability to write narrative in pretest and posttest of experimental group comparing with the control group by using Think Talk Write (TTW) strategy.

Scoring classification of the students' pretest in experimental and control group

Students' scores of posttest were classified also into five classifications namely very good, good, average, poor, and very poor. The frequency and the rate percentage of the students' score of pretest in experimental and control group are described as follows:

Table 3 The rate percentage and frequency of students' scores of pretest in experimental and control group

\begin{tabular}{lccccc}
\hline \multirow{2}{*}{ Classification } & \multirow{2}{*}{ Score } & \multicolumn{2}{c}{ Experimental Group } & \multicolumn{2}{c}{ Control Group } \\
\cline { 3 - 6 } & & Frequency & Percentage & Frequency & Percentage \\
\hline Very good & $86-100$ & 0 & 0 & 0 & 0 \\
Good & $71-85$ & 0 & 0 & 0 & 0 \\
Average & $56-70$ & 13 & 43.33 & 15 & 50.00 \\
Poor & $41-55$ & 15 & 50.00 & 14 & 46.67 \\
Very poor & $0-40$ & 2 & 6.67 & 1 & 3.33 \\
$\quad$ TOTAL & & $\mathbf{3 0}$ & $\mathbf{1 0 0}$ & $\mathbf{3 0}$ & $\mathbf{1 0 0}$ \\
\hline
\end{tabular}

Based on the data shown in Table 1 above, the result of pretest of both groups is none or $0 \%$ of students got "very good" and "good score" score. In experimental group, there were $13(43.33 \%)$ students got "average", 15 (50.00\%) students "poor", and $2(6.67 \%)$ students got "very poor". While in control group, there were $15(50.00 \%)$ students got "average", 14 (46.67\%) students "poor", and $1(3.33 \%)$ students got "very poor". 
Scoring classification of the students' posttest in experimental and control group

Students' score of posttest were classified also into five classifications. The frequency and the rate percentage of the students' score of pretest and posttest in experimental group are described as follows:

Table 4 The rate percentage and frequency of students' scores of posttest in experimental and control group

\begin{tabular}{cccccc}
\hline \multirow{2}{*}{ Classification } & \multirow{2}{*}{ Score } & \multicolumn{2}{c}{ Experimental Group } & \multicolumn{2}{c}{ Control Group } \\
\cline { 2 - 6 } & & Frequency & Percentage & Frequency & Percentage \\
\hline Very good & $86-100$ & 2 & 6.67 & 0 & 0 \\
Good & $71-85$ & 15 & 50.00 & 5 & 16.67 \\
Average & $56-70$ & 10 & 33.33 & 17 & 56.67 \\
Poor & $41-55$ & 3 & 10.00 & 8 & 26.67 \\
Very poor & $0-40$ & 0 & 0 & 0 & 0 \\
TOTAL & & $\mathbf{3 0}$ & $\mathbf{1 0 0}$ & $\mathbf{3 0}$ & $\mathbf{1 0 0}$ \\
\hline
\end{tabular}

Based on the data shown in Table 4 above, the result of posttest in experimental group, there were $2(6.67 \%)$ students got "very good", $15(50.00 \%)$ students "good", 10 (33.33\%) students got "average", 3 (10.00\%) students got "poor", and none student got "very poor". While in control group, none students got "very good", 5 (16.67\%) students got "good", 17 (56.67\%) students "average", $8(26.67 \%)$ students got "poor", and none student got "very poor".

The comparison of posttest score in experimental and control group shows that there was significant difference in posttest result of both groups. It was proved by the result of posttest in both groups in which most of students in experimental group were categorized as "good" and some of them were in "very good" category. While in control group, most of students were categorized as "average" and none of them was categorized as "very good" even some of them were still categorized as "poor". It meant that overall it indicated that there was significant difference on the students' test result in posttest of both groups.

The comparison between the students' scores of pretest and posttest in experimental and control group.

The following table is the result of the students' score of pretest and posttest in control and experimental group. The tables show the difference score on mean score and standard deviation of both groups.

Table 5 The mean score and standard deviation of the students' pretest and post-test score

\begin{tabular}{llll}
\hline & Group & Mean Score & $\begin{array}{l}\text { Standard } \\
\text { Deviation }\end{array}$ \\
\hline Pre-test & Experimental & 56.27 & 6.554 \\
& Control & 57.83 & 5.509 \\
Post-test & Experimental & 71.56 & 9.99 \\
& Control & 61.43 & 8.76 \\
\hline
\end{tabular}


Based on table 5, the mean score of pretest in control group was 57.83 and experimental group was 56.27. From the table above, it can be concluded that the mean score of experimental group was the same as the control group because both groups was in the same category based on the scoring system namely in "average" category. We can also conclude that both experimental and control group have the same or relatively the same baseline knowledge in writing ability.

The table also showed that the mean scores of both experimental and control group were different after treatments. The mean score of experimental group was $71.56(56.23<71.56)$ whereas the control group was $61.43(55.50<61.43)$. The mean score of posttest for experimental group is higher than control group (71.56 $>61.43$ ) and the standard deviation for experimental group was 9.99 and control group was 8.76. The mean score of post-test in both groups also shows that both groups were in different category based on the scoring system in which the experimental group was in "good" and the control group was still in "average" category. It means that after giving the treatment, the result of experimental group on the mean score was higher than the control group. Therefore, it can be proved that the use of Think Talk Write (TTW) strategy improved the students' writing ability.

\section{Test of significance (t-test)}

The hypotheses were tested by using inferential analysis. In this case, the researcher used t-test (test of significance) for independent sample test, that is, a test to know the significant difference between the result of students' scores in pretest and posttest in control group and experimental group. The level of significance $(0.05)$ with degrees of freedom $(d f)=n 1+n 2-2$, where $n=$ number of subject (30). The following table shows the result of the calculation.

Table 6. The probability value of t-test of pretest in experimental and control group

\begin{tabular}{lcc}
\hline \multicolumn{1}{c}{ Variable } & Probability Value & $(\alpha)$ \\
\hline $\begin{array}{l}\text { Pretest of control and } \\
\text { experimental group }\end{array}$ & 0.314 & 0.05 \\
\hline
\end{tabular}

Based on the result of data analysis as summarized in Table 6 above in pretest of control and experimental group, the researcher found that the Probability Value is higher than alpha $(\alpha)(0.314>0.05)$ which means that there is no significant difference in pretest of both groups, while the P-value of posttest can be seen in Table 7.

Table 7. The probability value of t-test of posttest in experimental and control group

\begin{tabular}{lcc}
\hline \multicolumn{1}{c}{ Variable } & Probability Value & $(\alpha)$ \\
\hline $\begin{array}{l}\text { Posttest of control and } \\
\text { experimental group }\end{array}$ & 0.000 & 0.05 \\
\hline
\end{tabular}


Based on the result of data analysis as summarized in Table 7, the researcher found that the probability value is lower than alpha $(\alpha)(0.000<0.05)$ and the degree of freedom 58 which means that there is significant difference in posttest. It indicated that the null hypothesis $\left(\mathrm{H}_{1}\right)$ was accepted and, of course, the alternative hypothesis $\left(\mathrm{H}_{0}\right)$ was rejected. It showed that the implementation of TTW strategy significantly improves the students' writing ability.

\section{References}

Chaplen, Frank. (1970). Paragraph Writing. London: Oxford University Press.

Dixon, Carol N., Nessel, Denise. (1983). Language Experience Approach to Reading and Writing. New Jersey: Prentice Hall, Inc.

Eanes, Robin. (1997). Content Area Literacy: Teaching for Today and Tomorrow. Albany: Delmar publisher.

Gay, L.R., Geoffrey E. Mills, and Peter, Airasian. (2006). Educational Research: Competencies for Analysis and Application (Eight Edition). Columbus: Pearson Prentice Hall.

Jacobs, Holly L., et al. (1981). Testing ESL Composition: A Practical Approach. Massachusets: Newburry House Publishers, Inc.

Naidu, Mumtaz. (2007). The Use of Written Feedback and Conferencing in Improving Students' Writing. Online.

(http://eprints.utm.my/6459.MumtazV.CNaidu@MahadirNaiduMFP.pdf) Accessed on October 13, 2011.

Oshima, A., \& Hogue, A. (2006). Writing Academic English (4th edition). New York: Andison Wesley.

Parker, John F. (1983). The Process of Writing. United State of America: Addison Wesley.

Rahman, Abdul. (2010). The Application of Collaborative Dictogloss Technique in Increasing The Students' Writing Skill. Unpublished Thesis. Graduate Program State University of Makassar.

Rostina. (2011). Pengaruh Penerapan Strategi Pembelajaran Think Talk Write terhadap Hasil Belajar dan Keterampilan berpikir Siswa SMA Negeri.1.Labakkang pada Materi Evolusi. Unpublished Thesis. Graduate Program State University of Makassar.

Trianata, Ita Yuli. (2010). Developing Narrative Writing Performance of the First Grade at SMAN 1 Bau-Bau Based on Their Experience. Unpublished Thesis. Graduate Program State University of Makassar. 